\title{
Marsupialization of Juvenile Paradental Cyst: A Case Report
}

\author{
Jelena Stepić, Marko Pejović, Snježana Čolić \\ Department of Oral Surgery, School of Dentistry, University of Belgrade, Belgrade, Serbia
}

\begin{abstract}
SUMMARY
Juvenile paradental cysts (JPC) are rare cystic lesions that usually develop on buccal, distal, or mesial side of first, and rarely second permanent mandibular molars. They occur during tooth eruption, in children aged 6 to 12 years, and belong to the group of inflammatory paradental cysts. Clinical symptomatology is scarce and often manifested as appearance of painless swelling on the buccal side of the offending tooth. Different therapeutic procedures could be used: enucleation, enucleation with tooth extraction or marsupialization. This study presents the marsupialization procedure of bilateral JPC attached to the first permanent lower molars in seven year old girl.
\end{abstract}

Keywords: juvenile paradental cyst; marsupialization

\section{INTRODUCTION}

Paradental cysts are rare cystic lesions that develop on buccal, distal and rarely mesial side of the mandibular permanent molars in the period of their eruption. They belong to the group of inflammatory cysts and constitute less than $5 \%$ of all odontogenic cysts [1]. Most often they are associated with recurrent pericoronitis of semi-impacted wisdom teeth $(61.4 \%)$ at the time of their eruption, between age 17 and 25. When localized on the buccal side of first and second mandibular molars (35.9\%), they manifest at age 6-12 years [1]. Then, they are named juvenile paradental cysts (JPC) [2]. Very rarely, this cyst can develop on other teeth $[3,4]$.

Etiology and pathogenesis of these cysts have not been fully clarified. It is believed that inflammation of superficial periodontal tissue during eruption is initial factor that stimulates proliferation of odontogenic epithelium responsible for the development of cystic lesions $[1,5]$. This theory is supported by the fact that the time of cyst appearance coincides with the time of tooth eruption. The origin of proliferating epithelium is not yet known: it might be derived from reduced enamel epithelium, junctional epithelium, epithelial remnants of dental lamina or epithelial rests of Malassez $[1,6,7]$.

Histopathological finding of juvenile paradental cyst is not specific because it corresponds to radicular cysts [ 1 , $5,8]$. It is characterized by hyperplastic non-keratinized stratified squamous epithelium and a layer of connective tissue with presence of inflammatory infiltrate $[1,5,6,7$, 9]. Therefore, diagnosis is primarily established on the basis of clinical and radiographic findings. Differential diagnosis will consider lateral radicular cyst, lateral periodontal cyst and keratocystic odontogenic tumor.

Different therapeutic procedures could be used: enucleation, enucleation with tooth extraction or marsupi- alization. For mandibular wisdom teeth enucleation with tooth extraction is recommended, while for JPC there is no established protocol, but conservative treatment has priority due to the importance of first and second molars and patient age.

This case report describes conservative surgical approach in the treatment of bilateral juvenile paradental cysts attached on the first lower permanent molars.

\section{CASE REPORT}

Seven year-old girl showed up at the Clinic for Oral Surgery, School of Dentistry in Belgrade due to localized area of swelling in the vestibule of mandibular left first molar. Her parent indicated that swelling occurred one month earlier and continued to grow slowly. Clinical examination revealed mild painless swelling on the buccal side of intact, incompletely erupted mandibular left first permanent molar. Surrounding mucous membrane was noninflamed, with normal color and without presence of suppuration in the affected region. Ortopantomography revealed two oval cystic formations in the root area of first mandibular molars, and in close contact with the germs of non erupted second mandibular permanent molars. Lamina dura of the affected teeth was preserved, except around distal root of the first lower right molar, where lamina dura could not be identified. Cysts had definite borders and diameter of $13 \times 18 \mathrm{~mm}$ on the left and $14 \times 20$ $\mathrm{mm}$ on the right side of jaw (Figure 1).

Both cysts were treated by marsupialization. One hour before intervention the patient received prophylactic antibiotic protection (500 $\mathrm{mg}$ Hemomycin per os) due to mitral valve prolapse.

After administration of local anesthesia a flap was lifted on the buccal side of the left lower first molar. Thereafter, 


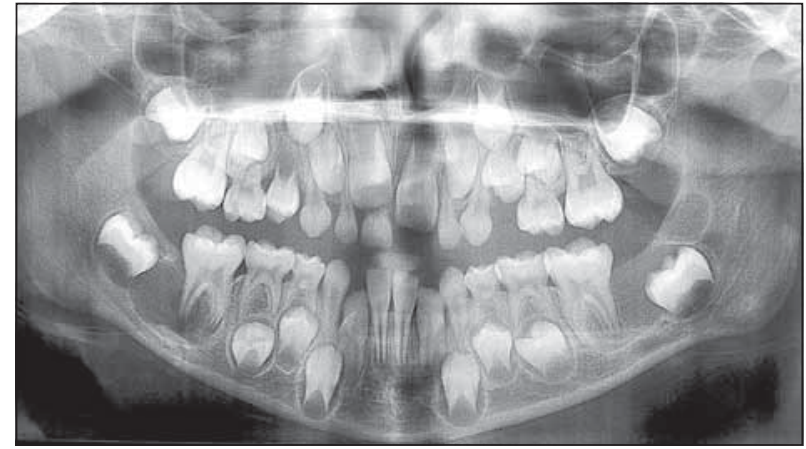

Figure 1. Orthopantomogram: two radiolucent lesions are observed in the region of left and right lower first permanent molar

Slika 1. Ortopantomogram: uočavaju se dva jasno ograničena ovalna rasvetljenja u predelu levog i desnog prvog donjeg stalnog molara

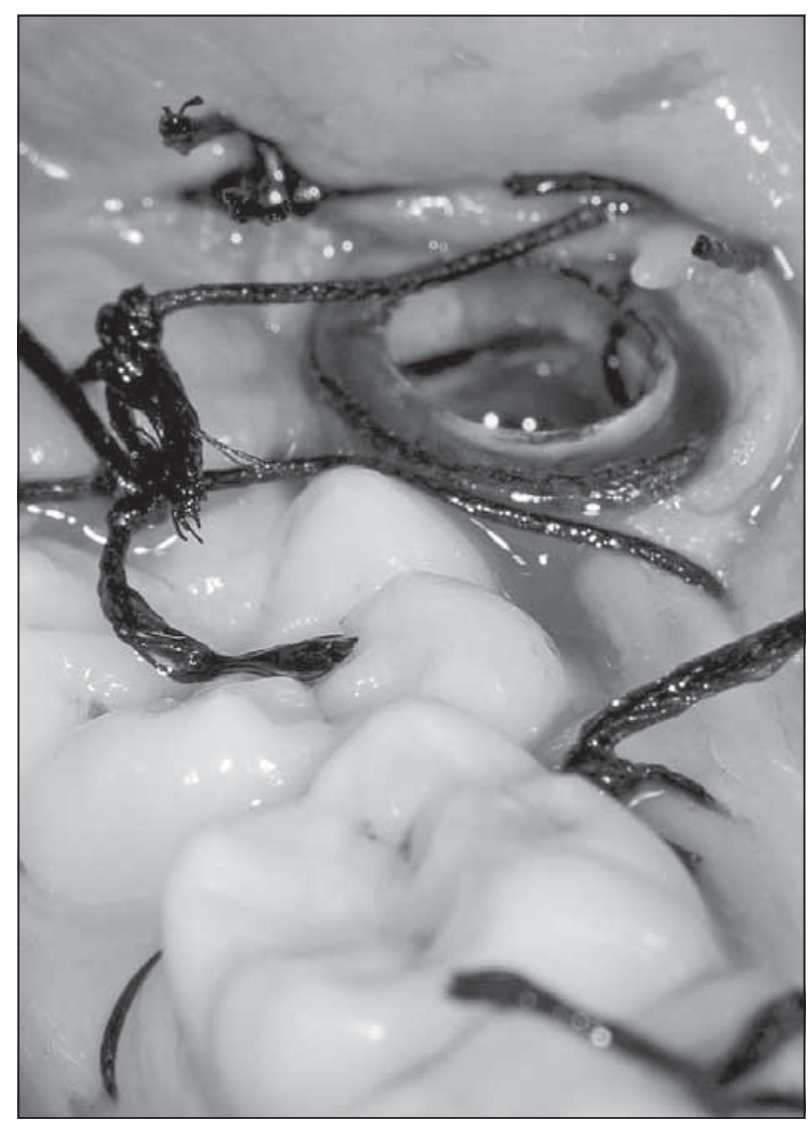

Figure 2. Polyethylene tubing set for irrigation of cystic cavity Slika 2. Postavljena polietilenska cevčica za ispiranje cističnog kaviteta

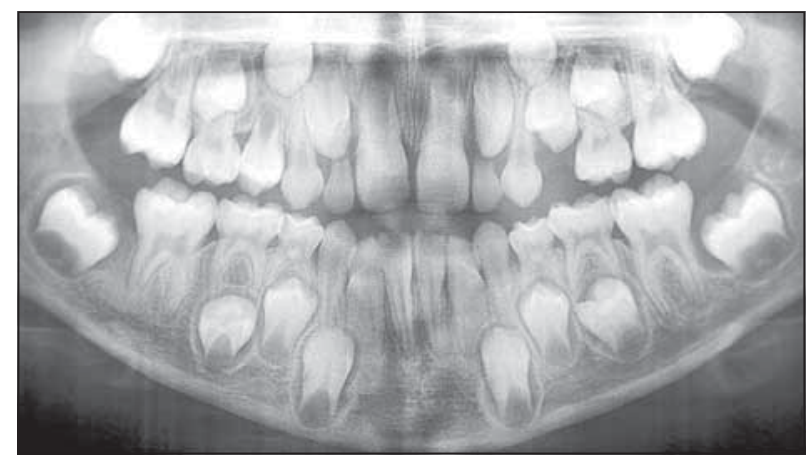

Figure 3. Control radiograph after four months: cystic defects were completely filled with bone tissue

Slika 3. Kontrolni radiogram nakon četiri meseca: cistični defekti su potpuno ispunjeni koštanim tkivom

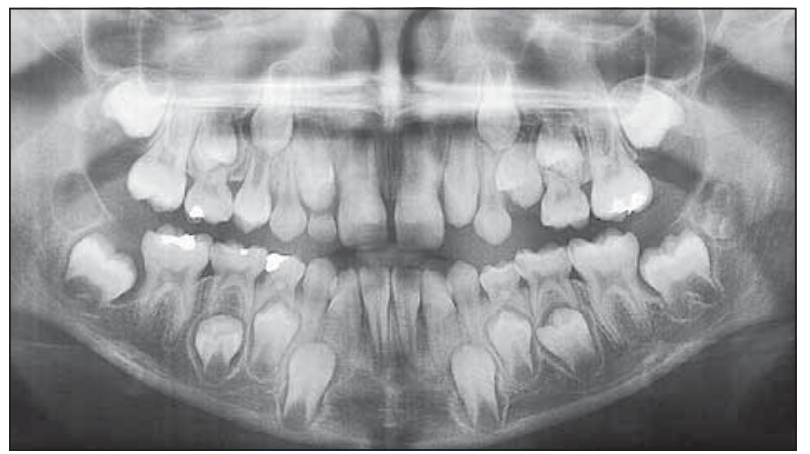

Figure 4. Control radiograph one year after surgery: without pathological changes or recidive

Slika 4. Kontrolni radiogram godinu dana nakon hirurške intervencije: bez patoloških promena i recidiva

the trephination of buccal cortex was performed to approach the cyst. During the procedure, a part of cyst sac was obtained for histopathological verification while thick, yellowish cystic content was rinsed with saline. Then, polyethylene tubing was set and attached, the flap was repositioned and individual sutures applied (Figure 2 ). The same procedure was repeated on the opposite side of the jaw, but the drainage was established using iodoform gauze which was regularly changed while the cyst was rinsed with saline. There was no need for continuation of antibiotic therapy postoperatively.

Cysts were irrigated daily for one month and a half, or until spontaneous closure of the defect occurred. Histopathology confirmed that these cysts were inflammatory cysts, and the patient was followed for one year.

Four months after the intervention the control ortopantomography showed that both cyst defects were partly filled with newly formed bone while root growth was completed on the first lower molars (Figure 3). Clinical finding was normal with no swelling and inflammation present. One year later, the control radiograph showed no pathological changes or recidive (Figure 4).

\section{DISCUSSION}

According to the classification of the World Health Organization, beside radicular cysts, paradental cysts also belong to the group of inflammatory cysts [5]. This type of lesion was published in the English literature for the first time in 1970 [3]. Since then, a number of different names have been used to define paradental inflammatory cysts $[3,5-8]$.

These cysts represent $0.9-4.7 \%$ of all odontogenic cysts. The average age of patients with juvenile paradental cysts varies in relation to the affected tooth and whether it occurs in male or female. Juvenile paradental cysts are more likely to develop in first molars as compared to other permanent molars of the lower jaw. The average age for males is around 9 and for females 8.1. In 23.9\% juvenile paradental cysts may be bilateral [1]. Other authors have reported that $37.5 \%$ of JPC occured bilaterally, and even in $25 \%$ they were asymptomatic [6]. As there is a tendency for bilateral occurrence, radiographic examination of the opposite side should be performed. Stoneman and 
Worth [8] have suggested that these cysts were usually asymptomatic or with existence of minimal symptoms. However, if symptoms are present, they can manifest as discomfort, spontaneous pain or during mastication, and rarely suppuration. In this case report, a slight swelling and discomfort have prompted the patient to seek for help to the dentist.

In the past, juvenile paradental cysts have routinely been enucleated with or without tooth extraction $[1,6,8$, $10,11,12]$. Currently, the therapeutic protocols for these lesions have amended in accordance with conservative surgical approach and preservation of dental arch integrity. In fact, the extraction of first and second molars can significantly impair the development of alveolar processes and dental arches, therefore, whenever possible extraction of these teeth should be avoided. David et al. [7] have described a method of micromarsupialization based on rinsing the cystic lumen with saline through the periodontal pocket. They also reported two cases of spontaneous resolution of JPC, which Pompura et al. [6] interpreted as the result of microtrauma that probably caused automarsupialization. These authors believe that this method can be applied to the smaller asymptomatic lesions, while infected and larger cysts require surgical treatment. In the recent literature, several cases of spontaneous resolution of the JPC have also been described $[13,14]$.

The method of marsupialization with the drainage is mainly used in the treatment of large jaw cysts. That way, by reducing the pressure inside the cyst, surrounding bone and adjacent anatomical structures can be preserved and auto repaired. In the second surgical procedure, after the volume reduction of cyst, total enucleation is performed. In the presented case, there was no need for the second surgical intervention - enucleation, because complete regeneration of soft tissue and bone was achieved by rinsing the cyst only.

Marsupialization is method of choice for the treatment of JPC because of great regenerative potential of bone tissue in children. By this method, periodontal ligament is also preserved which would be removed by the process of enucleation. The drawbacks of this procedure are long- term check-ups for rinsing the cyst lumen and risk for prolonged existence of pathological tissue in the body.

\section{REFERENCES}

1. Philipsen HP, Reichart PA, Ogawa I, Suei Y, Takata T. The inflammatory paradental cyst: a critical review of 342 cases from a literature survey, including 17 new cases from the author's files. J Oral Pathol Med. 2004; 33:147-55.

2. Shear M, Speight PM. Cyst of the Oral and Maxillofacial Regions. 4th ed. Oxsford: Blackwell-Munksgaard; 2007.

3. Main DMG. Epithelial jaw cysts: a clinicopathological reappraisal. Br J Oral Surg. 1970; 8:114-25.

4. Morimoto Y, Tanaka T, Nishida I, Kito S, Hirashima S, Okabe S, et al. Inflammatory paradental cyst (IPC) in the mandibular premolar region in children. Oral Surg Oral Med Oral Pathol Oral Radiol Endod. 2004; 97:286-93.

5. Kramer IRH, Pindborg J], Shear M. Histological Typing of Odontogenic Tumors. 2nd ed. Berlin: Springer-Verlag; 1992.

6. Pompura JR, Sándor GKB, Stoneman DW. The buccal bifurcation cyst - a prospective study of treatment outcomes in 44 sites. Oral Surg Oral Med Oral Pathol Oral Radiol Endod. 1997; 83:215-21.

7. David LA, Sándor GKB, Stoneman DW. The buccal bifurcation cyst: Is non-surgical treatment and option? J Can Dent Assoc. 1998; 64:712-6.

8. Stoneman DW, Worth HM. The mandibular infected buccal cyst - molar area. Dent Radiogr Photogr. 1983; 56:1-14.

9. Silva TA, Batista AC, Camarini ET, Lara VS, Consolaro A. Paradental cyst mimicking a radicular cyst on the adjacent tooth: case report and review of terminology. J Endod. 2003; 29:73-6.

10. Main DM. Epithelial jaw cysts: 10 years of the WHO classification. J Oral Pathol. 1985; 14:1-7.

11. Lim AA-T, Peck RH-L. Bilateral mandibular cyst: lateral radicular cyst, paradental cyst, or mandibular infected buccal cyst? Report of a case. J Oral Maxillofac Surg. 2002; 60:825-7.

12. Lacaita MG, Capodiferro S, Favia G, Santarelli A, Muzio LL. Infected paradental cysts in children: a clinicopathological study of 15 cases. $\mathrm{Br} J$ Oral Maxillofac Surg. 2006; 44:112-5.

13. Corona-Rodriguez J, Torres-Labardini R, Velasco-Tizcareño M, MoraRincones $O$. Bilateral buccal bifurcation cyst: case report and literature review. J Oral Maxillofac Surg. 2011; 69:1694-6.

14. Zadik Y, Yitschaky O, Neuman T, Nitzan DW. On the self-resolution nature of the buccal bifurcation cyst. J Oral Maxillofac Surg. 2011; 69:e282-4. 


\title{
Marsupijalizacija juvenilne paradentalne ciste - prikaz slučaja
}

\author{
Jelena Stepić, Marko Pejović, Snježana Čolić \\ Klinika za oralnu hirurgiju, Stomatološki fakultet, Univerzitet u Beogradu, Beograd, Srbija
}

\begin{abstract}
KRATAK SADRŽAJ
Juvenilne paradentalne ciste (JPC) su retke cistične lezije koje se uglavnom razvijaju na bukalnoj, distalnoj ili mezijalnoj strani prvog, a znatno ređe drugog stalnog molara u donjoj vilici. Nastaju tokom njihovog nicanja kod dece uzrasta 6-12 godina i pripadaju grupi inflamatornih paradentalnih cista. Kliničkih simptoma je vrlo malo, a oboljenje se najčešće ispoljava u vidu bezbolnog otoka sa bukalne strane zahvaćenih zuba. Terapijski pristup podrazumeva enukleaciju, enukleaciju sa vađenjem zuba ili marsupijalizaciju. Prikazujemo slučaj marsupijalizacije bilateralne JPC prvih stalnih donjih molara kod sedmogodišnje devojčice.
\end{abstract}

Ključne reči: juvenilna paradentalna cista; marsupijalizacija

\section{UVOD}

Paradentalne ciste su retke cistične lezije koje se razvijaju na bukalnoj, distalnoj i ređe mezijalnoj strani donjih stalnih molara tokom njihovog nicanja. Pripadaju grupi inflamatornih cista i čine manje od 5\% svih odontogenih cista [1]. Najčešće su udružene s recidivantnim perikoronitisom poluimpaktiranih donjih umnjaka $(61,4 \%)$ tokom njihovog nicanja, između 17. i 25. godine. Kada su lokalizovane sa bukalne strane prvih i drugih donjih stalnih molara (35,9\%), postaju manifestne u uzrastu 6-12 godina [1]. Tada se nazivaju juvenilne paradentalne ciste (JPC) [2]. Izuzetno retko mogu se razviti i na drugim zubima $[3,4]$.

Etiologija i patogeneza ovih cista nisu potpuno razjašnjene. Smatra se da je zapaljenje površinskog dela periodoncijuma zuba u nicanju inicijalni faktor koji stimuliše proliferaciju odontogenog epitela, odgovornog za nastanak cistične lezije $[1,5]$. Ovoj teoriji u prilog ide to što se vreme pojavljivanja ciste podudara s vremenom nicanja zuba. Još, međutim, nije poznato da li proliferiše redukovani gleđni epitel, pripojni epitel, ili proliferišu epitelni ostaci dentalne lamine, odnosno Malasezova epitelna ostrvca $[1,6,7]$.

Ni histopatološki nalaz paradentalnih cista nije specifičan, jer odgovara nalazu radikularne ciste $[1,5,8]$. Odlikuju ga hiperplastični pločasto-slojevit epitel bez orožavanja i vezivnotkivni omotač sa zapaljenjskim infiltratom [1, 5, 6, 7, 9]. Stoga se dijagnoza prevashodno postavlja na osnovu kliničkog i radiografskog nalaza. Diferencijalnodijagnostički u obzir dolaze lateralna radikularna cista, lateralna periodontalna cista i keratocistični odontogeni tumor.

Terapijski pristup podrazumeva enukleaciju, enukleaciju sa vađenjem zuba ili marsupijalizaciju. Za donje umnjake se preporučuje enukleacija sa vađenjem zuba, dok za JPC ustanovljenih protokola nema, ali se teži konzervativnom lečenju s obzirom na značaj prvog i drugog molara i uzrast pacijenta.

U ovom prikazu slučaja opisan je konzervativni hirurški pristup u lečenju dve JPC na prvim donjim stalnim molarima.

\section{PRIKAZ SLUČAJA}

Sedmogodišnja devojčica je primljena na Kliniku za oralnu hirurgiju Stomatološkog fakulteta Univerziteta u Beogradu zbog lokalizovanog otoka u predelu forniksa donjeg prvog molara s leve strane. Roditelj pacijentkinje je rekao da se otok pojavio mesec dana ranije, a zatim postepeno uvećavao. Kliničkim pregledom uočen je mali bezbolni otok sa bukalne strane intaktnog, nepotpuno izniklog prvog levog donjeg stalnog molara. Okolna sluzokoža bila je neinflamirana, normalno prebojena i bez supuracije iz zahvaćene regije. Ortopantomografski snimak je pokazao da postoje dve ovalne cistične formacije u predelu korena prvih donjih stalnih molara koje su bile u bliskom kontaktu s klicama neizniklih drugih donjih stalnih molara. Periodontalna linija i lamina dura zahvaćenih zuba bile su očuvane izuzev oko distalnog korena prvog donjeg desnog molara, gde laminu duru nije bilo moguće prepoznati. Ciste su bile jasno ograničene, prečnika $13 \times 18 \mathrm{~mm}$ na levoj $14 \times 20 \mathrm{~mm}$ na desnoj strani vilice (Slika 1).

Obe ciste tretirane su marsupijalizacijom. Devojčica je sat vremena pre intervencije primila antibiotsku profilaktičku zaštitu (500 mg hemomicina per os) zbog prolapsa mitralne valvule.

U lokalnoj anesteziji odignut je mukoperiostalni režanj sa bukalne strane prvog levog donjeg molara, nakon čega je trepaniran deo bukalnog korteksa, kako bi se pristupilo cisti. U istom aktu uzet je deo cističnog sakusa za histopatološku potvrdu, a gust, žućkasto prebojen cistični sadržaj dobro je ispran fiziološkim rastvorom. Potom je postavljena i pričvršćena polietilenska cevčica, nakon čega je režanj reponiran i ušiven pojedinačnim šavovima (Slika 2). Isti postupak ponovljen je na suprotnoj strani vilice, s tim što je drenaža uspostavljena primenom jodoform-štrajfne, koja je redovno menjana, a cista redovno ispirana fiziološkim rastvorom. Posle operacije nije bilo potrebe da se nastavi primena antibiotske terapije.

Ciste su ispirane svakodnevno narednih mesec i po dana, odnosno dok nije došlo do spontanog zatvaranja defekta, kada dalje ispiranje nije bilo svrsishodno. Histopatološki nalaz potvrdio je da je reč o inflamatorim cistama, a pacijentkinja je kontrolisana narednih godinu dana.

Na kontrolnom ortopantomografskom snimku četiri meseca nakon intervencije na obe stane vilice uočeni su popunjavanje cističnih defekata novoformiranim koštanim tkivom i završen rast korenova prvih donjih stalnih molara (Slika 3). Klinički nalaz bio je normalan, bez otoka i zapaljenja. Godinu dana kasnije kontrolni snimak je pokazao da nema patoloških promena, niti recidiva (Slika 4). 


\section{DISKUSIJA}

Prema klasifikaciji Svetske zdravstvene organizacije, pored radikularnih cista, inflamatornim odontogenim cistama pripadaju i paradentalne ciste [5]. Ova vrsta lezije je u literaturi na engleskom jeziku prvi put opisana 1970. godine [3]. Otada do danas koristi se niz različitih naziva kojima se definiše inflamatorna paradentalna cista $[3,5-8]$.

Ove ciste čine $0,9-4,7 \%$ svih odontogenih cista. Prosečna starost pacijenata koji imaju JPC se razlikuje u odnosu na zub koji je zahvaćen i u odnosu na to da li se javlja kod osoba muškog ili ženskog pola. JPC se razvijaju češće na prvim nego na drugim stalnim molarima donje vilice. Kada su u pitanju prvi molari, prosečna starost pacijenata muškog pola je devet godina, a pacijenata ženskog pola 8,1 godina. U $23,9 \%$ slučajeva JPC mogu biti obostrane [1]. Drugi autori navode da je 37,5\% JPC bilateralno, a da je u čak 25\% slučajeva druga lezija asimptomatska [6]. Kako postoji sklonost da se ove ciste jave na obe strane, uvek treba radiografisati i suprotnu stranu vilice. Stonman (Stoneman) i Vort (Worth) [8] smatraju da su ove ciste uglavnom asimptomatske ili su simptomi veoma slabi. Ukoliko simptomi postoje, manifestuju se nelagodnošću, bolom koji se javlja pri zagrižaju, a retko supuracijom. U opisanom slučaju upravo su blagi otok i nelagodnost bili uzroci javljanja pacijenta stomatologu.

U prošlosti su JPC bile rutinski enukleirane uz ekstrakciju ili čuvanje zahvaćenog zuba $[1,6,8,10,11,12]$. Danas su terapijski protokoli ovih lezija izmenjeni u skladu s konzervativnim hirurškim pristupom i očuvanjem integriteta zubnog niza.
Naime, vađenje prvog i drugog molara značajno može narušiti razvoj alveolarnih nastavaka i zubnih lukova, pa se terapijskim pristupom izbegava njihovo vađenje kad god je to moguće. Dejvid (David) i saradnici [7] su opisali metodu mikromarsupijalizacije, koja se zasniva na ispiranju cističnog lumena fiziološkim rastvorom kroz parodontalni džep. Takođe su zabeležili dva slučaja spontanog povlačenja JPC koje, prema Pompuri (Pompura) i saradnicima [6], tumače kao posledicu mikrotraume koja je verovatno dovela do automarsupijalizacije. Ovi autori smatraju da se takva metoda može primeniti kod asimptomatskih lezija manjih dimenzija, odnosno da je inficirane i ciste većih dimenzija potrebno hirurški odstraniti. U novijoj literaturi takođe su opisani slučajevi spontanog povlačenja JPC [13, 14].

Metoda marsupijalizacije primenom drenaže uglavnom se koristi u terapiji velikih viličnih cista. Na taj način se smanjenjem pritiska u cisti omogućava samoobnavljanje i čuvaju okolna kost i susedne anatomske strukture. Zatim se, nakon smanjenja volumena ciste, u drugom aktu vrši enukleacija ciste. U prikazanom slučaju nije bilo potrebe za drugom fazom - enukleacijom, jer je ispiranjem ciste postignuta potpuna regeneracija i mekih i koštanih tkiva.

Kada su u pitanju JPC, marsupijalizacija može biti metoda izbora u lečenju ovih lezija, jer se računa na veliki regenerativni potencijal koštanog tkiva kod dece. Na ovaj način se istovremeno doprinosi očuvanju periodontalnog ligamenta, koji bi primenom enukleacije bio iskiretiran. Kao nedostaci ovakve terapije navode se dugotrajni kontrolni pregledi zbog ispiranja ciste i rizik od zadržavanja patološkog tkiva u organizmu. 